\title{
The origin of nitrogen incorporated into compounds in the rumen bacteria of steers given protein- and urea-containing diets
}

\author{
By D. N. SALTER, K. DANESHVAR* AND R. H. SMITH \\ National Institute for Research in Dairying, Shinfield, Reading $R G 29 A T$ \\ (Received 13 December 1977 - Accepted 24 July 1978)
}

I. Two young Friesian steers fitted with rumen cannulas were each given three different isonitrogenous and isoenergetic diets for successive periods of 2-3 weeks. The diets consisted mainly of straw and tapioca, with the nitrogen supplied mainly as decorticated groundnut meal (DCGM; $\operatorname{diet} \mathrm{A}$ ), in approximately equal amounts of DCGM and urea (diet B), or entirely as urea (diet C).

2. At the end of each period on a given diet, part of the dietary urea of a morning feed was replaced by a solution of $\left[{ }^{15} \mathrm{~N}\right]$ urea which was infused into the rumen. Samples of rumen contents were removed just before giving the ${ }^{15} \mathrm{~N}$ dose and at $\mathrm{r}, 3,5,7$ and $24 \mathrm{~h}$ afterwards, concentrations of ammonia and its ${ }^{15} \mathrm{~N}$ enrichment were determined and samples of mixed bacteria were prepared. Amino acids, ammonia derived mainly from amide groups, and hexosamines were prepared by ion-exchange chromatography of acid-hydrolysates of the bacteria and analysed for ${ }^{15} \mathrm{~N}$.

3. Approximate estimates of net bacterial $\mathrm{N}$ synthesis were made from turnover data for rumen fluid and ${ }^{15} \mathrm{~N}$ enrichments in rumen fractions. From the determined efficiency of incorporation of urea- $\mathrm{N}$ into bacteria recovered at the duodenum, it was calculated that on diets $\mathrm{A}, \mathrm{B}$ and $\mathrm{C}$ respectively $82 \%, 37 \%$ and $\mathrm{o} \%$ of the bacterial $\mathrm{N}$ was derived from dietary protein or other non-urea sources.

4. $\left[{ }^{15} \mathrm{~N}\right]$ urea was converted rapidly to ammonia and the ${ }^{16} \mathrm{~N}$ then incorporated into bacterial amide- $\mathrm{N}$; it appeared at a slower rate in total bacterial non-amide-N. Rates of incorporation into non-amide-N were highest for glutamic acid, aspartic acid and alanine, and generally lowest for proline (pro), histidine (his), phenylalanine (phe), arginine ( $\mathrm{arg}$ ), methionine (met) and galactosamine. A similar ranking was also generally observed for relative ${ }^{15} \mathrm{~N}$ abundances $\left({ }^{15} \mathrm{~N}\right.$ atoms \% excess in $\mathrm{N}$ component $\div{ }^{15} \mathrm{~N}$ atoms $\%$ excess in total bacterial $\mathrm{N}$ ) achieved after several hours. Relative ${ }^{15} \mathrm{~N}$ abundances in his, arg and pro increased with decreasing protein (DCGM) in the diet but those in the other protein amino acids, including the poorly labelled met, phe (and its derivative tyrosine) did not.

5. It was concluded that different extents of labelling of the amino acids (at least those present mainly in protein) indicated that different amounts of preformed units (amino acids or peptides) were used. When an adequate supply of such units was available (particularly on diet A) pro, arg, his, met and phe were derived in this way to a greater extent than the other amino acids, but whereas synthesis of pro, arg and his increased on the low-protein diet $\mathrm{C}$, that of met and phe did not. Thus met and phe may be limiting for bacterial growth on diets low in protein and high in non-protein-N.

6. Differences in the extent of labelling of other bacterial $\mathrm{N}$ components may be due to different turnover rates.

In ruminant feeding, an important factor determining the amount of amino acid-nitrogen flowing from the rumen into the duodenum is the amount of dietary energy that is required to support a given level of synthesis of bacterial $\mathrm{N}$ compounds in the rumen. A survey of the available literature (Roy et al. 1977) indicates a mean value for this relationship of I.25 MJ metabolizable energy/g microbial $\mathrm{N}$ incorporated, but individual estimates may vary widely. There are a number of possible reasons for such variation (discussed for example by Smith (1976)) including differences in the amounts of preformed nutrients supplied. Several studies have indicated that although the mixed bacterial population uses ammonia as its main nitrogenous nutrient it may also use, in part, preformed amino acids or peptides if these are available (e.g. Nolan \& Leng, 1972). It is also known that, in pure culture, some species of rumen bacteria require supplies of certain amino acids or their carbon skeletons in a preformed state (Bryant, 1973). It appears possible therefore that although bacterial protein synthesis will occur in the rumen even on diets in which urea is

* Present address: Biochemical and Bioenvironmental Research Centre, Arya-Mehr University of Technology, Tehran, Iran. 
Table I. Daily intakes $(k g)$ of dietary constituents by steers

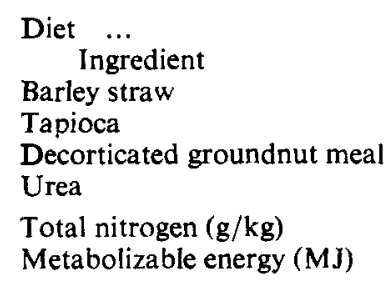

Mineral and vitamin ( $\mathrm{A}, \mathrm{D}$ and $\mathrm{E}$ ) supplements were also given. Total dietary sulphur: $\mathrm{N}$ values were approximately 0.10 in series $I$ experiments and 0.20 in series 2 experiments when additional potassium sulphate was given.

virtually the only $\mathrm{N}$ source, the extent of this synthesis may sometimes be limited by a deficiency of such preformed units. There is some experimental evidence to support this view (Hume, 1970; Maeng \& Baldwin, 1976) but it is not clear which amino acids are mainly implicated.

The main purpose of the present study was to compare the rates and extents of incorporation of ammonia- $\mathrm{N}$ labelled with ${ }^{15} \mathrm{~N}$ into individual bacterial nitrogenous components and to use this information to assess the relative extents to which different bacterial amino acids were synthesized or directly incorporated.

Preliminary communications on parts of the work have been published (Daneshvar et al. 1976; Salter, Daneshvar \& Smith, 1976).

\section{EXPERIMENTAL \\ Animals and diets}

Two series of experiments were done each with a Friesian steer aged $18-25$ weeks. The steers were fitted with rumen and simple duodenal cannulas and were given diets $A, B$ and $\mathrm{C}$ (Table 1 ), in that order, each diet for 2-3 weeks. The concentrate part of a diet was given in equal amounts at 09.00 and 16.00 hours but straw was given at 16.00 hours only. The diets were approximately isoenergetic and isonitrogenous the $\mathrm{N}$ being supplied mainly by urea or extracted decorticated groundnut meal (DCGM) or both in different amounts. Labelling and collection of bacterial samples was done at the end of each period during which a particular diet was given. At 09.00 hours on the day of such a procedure a solution containing $5 \mathrm{~g}\left[{ }^{15} \mathrm{~N}\right]$ urea (30 atoms $\%$ excess, double $\mathrm{N}$ label; Prochem, British Oxygen Co., Deer Park Road, London SW 19 ) and 100 g polyethylene glycol (PEG), molecular weight 4000 dissolved in and made up to $500 \mathrm{ml}$ with saline ( $5 \mathrm{~mm}$-sodium chloride) was introduced directly into the rumen via the cannula. At the same time the appropriate concentrate feed, but with the urea reduced by an amount equal to the $\left[{ }^{15} \mathrm{~N}\right] \mathrm{urea}$ dose, was introduced directly into the rumen in a coarsely ground form.

No further feed was given on the day of an experiment and water was not given during a period of $7 \mathrm{~h}$ after the infusion.

There was no indication of abnormality in the rumen processes. For example rumen $\mathrm{pH}$ values ranged from $7 \cdot 2-7 \cdot 45$ before feeding, fell to a minimum of $5 \cdot 20-5.8$ at $3 \mathrm{~h}$, and returned to $6 \cdot 70-7 \cdot 20$ between 5 and $7 \mathrm{~h}$ after feeding.

Collection of rumen contents. Samples of rumen contents (approximately 500g) were collected by means of a pump immediately before administering the $\left[{ }^{15} \mathrm{~N}\right]$ urea and at $\mathrm{I}, 3$, 5,7 and $24 \mathrm{~h}$ afterwards. The pump inlet tube was moved to different positions in the rumen 
during collection to ensure that each sample contained material reasonably representative of the total contents of the rumen.

Preparation of rumen bacteria. The samples of rumen contents were first strained through several layers of muslin to remove coarse particulate material. The strained fluid was diluted with $0.6 \mathrm{vol}$ saline and centrifuged at $200 \mathrm{~g}$ for $10 \mathrm{~min}$ at a temperature of $\mathrm{I}^{\circ}$ (MSE Mistral ${ }_{4} \mathrm{~L}$ centrifuge; Measuring \& Scientific Equipment Ltd, Manor Royal, Crawley, Sussex) to remove food particles. The supernatant fluid was then centrifuged at $30000 \mathrm{~g}$ for $10 \mathrm{~min}$ at $\mathrm{I}^{\circ}$ (MSE High Speed $\mathrm{I} 8$ centrifuge) to produce a sediment of crude bacteria. This was washed twice by resuspension in saline and repeating the centrifugation, then finally washed by resuspension in distilled water followed rapidly by centrifugation. The washed residue of bacteria was examined microscopically and found to be essentially free from all nonbacterial contaminants.

\section{Analytical methods}

Total $N$. Samples of suspensions of rumen bacteria (I g) containing about $\mathrm{I} \mathrm{mg} \mathrm{N}$ were digested and analysed for total $\mathbf{N}$ as previously described for digesta samples (Salter \& Smith, $1977 a$ ).

Ammonia. This was measured by the method of Conway (I957) in I $\mathrm{ml}$ samples of the strained rumen fluid preserved with $0.2 \mathrm{M}$-sulphuric acid. The term ammonia will be used here to include both the unionized and ionized forms unless otherwise stated.

Analysis of amino acids and hexosamines in rumen bacteria. A portion of the washed rumen bacterial sample containing $25 \mathrm{mg} \mathrm{N}$ in approximately $25 \mathrm{ml}$ was mixed with $6 \mathrm{M}$ hydrochloric acid to a total volume of $180 \mathrm{ml}$. The mixture was heated in an oil-bath at $110^{\circ}$ under reflux for $24 \mathrm{~h}$ to hydrolyse the bacterial proteins. The acid-hydrolysate was then filtered, dried by rotary evaporation under reduced pressure at $45^{\circ}$, redissolved in $5 \mathrm{ml}$ $0.2 \mathrm{M}$-citrate buffer $(\mathrm{pH} 2.2)$ to give a solution containing $5 \mu \mathrm{g} \mathrm{N} / \mathrm{ml}$ which was passed through a membrane filter (type HAWP02500, pore size $0.45 \mu \mathrm{m}$; Millipore (UK) Ltd, Millipore House, Abbey Road, London NW Io 7 SP). Quantitative amino acid analysis was carried out by ion-exchange chromatography of a portion of this solution containing $0.05 \mathrm{mg} \mathrm{N}$, using a JEOL amino acid analyser (JLC-5AH; Japan Electron Optics Laboratories Co Ltd, Toyko, Japan).

Preparation of amino acid, ammonia (from amide) and hexosamine fractions for ${ }^{15} \mathrm{~N}$ analysis. An EEL multichannel analyser (Evans ElectroSelenium Ltd, EEL/Corning, Halstead, Essex) was used to prepare amino acids, ammonia and hexosamines from a further portion of the hydrolysate for ${ }^{15} \mathrm{~N}$ analysis, using a sample load of $5 \mathrm{mg} \mathrm{N}$. As it was not possible to use an automatic ninhydrin reaction system to identify the amino acid peaks, these were located by means of a ninhydrin spot test. Eluted fractions of approximately I $\mathrm{ml}$ were collected and from each fraction a sample $(0.1 \mathrm{ml})$ was transferred to a boiling-tube containing $0.9 \mathrm{ml}$ distilled water. Ninhydrin reagent $(1 \mathrm{ml}$ of a solution containing $2 \mathrm{~g}$ indanetrione hydrate and $0.3 \mathrm{~g}$ hydrindantin in $75 \mathrm{ml} 2$-methoxyethanol and $4 \mathrm{M}$-sodium acetate buffer, $\mathrm{pH} 5 \cdot 5$, to bring the volume to $100 \mathrm{ml}$ ) was added to each diluted sample. The mixtures were then steamed in an autoclave at $100^{\circ}$ for $15 \mathrm{~min}$. After cooling, $8 \mathrm{ml}$ aqueous ethanol (ethanol:water; I:I, v/v) was added and the colour intensity measured. Good resolution was obtained and amino acids were easily identified from their relative positions.

Measurement of ${ }^{15} \mathrm{~N}$ in fractions from the amino acid analyser and in rumen ammonia. Fractions from the amino acid analyser were evaporated to dryness at $70^{\circ}$ in a $30 \mathrm{ml} \mathrm{Kjeldahl}$ flask. The dried residues were redissolved in $3 \mathrm{ml}$ concentrated sulphuric acid, catalyst ( $1.20 \mathrm{~g}$ potassium sulphate, $0.05 \mathrm{~g}$ mercuric oxide) added, and the mixtures digested as for total $\mathrm{N}$ determinations. After completion of digestion and cooling, the digests were diluted to $10 \mathrm{ml}$ with water. Portions of the diluted digest were used for the preparation of ${ }^{15} \mathrm{NH}_{4} \mathrm{Cl}$ 
and the measurement of ${ }^{15} \mathrm{~N}$ isotopic abundance as previously described (Lloyd-Jones et al. 1975) by means of optical emission spectrometry using a Statron NOI-4 ${ }^{15} \mathrm{~N}$-Analyser (CZ Scientific Ltd, Boreham Wood, Herts WD6 9NH).

For the determination of ${ }^{15} \mathrm{~N}$ in rumen ammonia, the acid-indicator mixture in the centre well of a Conway unit was replaced with $0.05 \mathrm{M}-\mathrm{HCl}(\mathrm{I} \mathrm{ml})$ and after completion of diffusion of the ammonia, the acid solution containing the labelled ammonium ions was withdrawn, evaporated to dryness and the residue redissolved in distilled water to give a solution containing I $\mu \mathrm{g} \mathrm{N} / 1$ as $\mathrm{NH}_{4} \mathrm{Cl}$ which was used for ${ }^{15} \mathrm{~N}$ analysis as described previously.

Estimation of bacterial $N$ synthesis. Approximate estimates of net synthesis of bacterial $\mathrm{N}$ were made from the fluid turnover rates determined with PEG and concentrations of bacterial $\mathrm{N}$ in the rumen fiuid. Bacterial $\mathrm{N}$ concentrations were calculated from the total non-ammonia $\mathrm{N}$ (NAN) concentration in strained rumen fiuid and the measured enrichments of ${ }^{15} \mathrm{~N}$ in rumen fluid NAN and in the separated bacteria. Net synthesis of bacterial $\mathrm{N}$ was calculated as rumen outflow of bacterial $\mathrm{N} / \mathrm{h}$, i.e. bacterial $\mathrm{N}$ concentration $\times$ rumen outflow on the assumption that the rumen volume remained constant throughout an experiment and that strained rumen contents were representative of digesta flowing from the rumen. The total bacterial $\mathrm{N}$ outflow over the $24 \mathrm{~h}$ period was calculated from the area under the time curve.

The proportion of urea $\mathrm{N}$ that was incorporated into bacteria was determined from the recovery of non-ammonia ${ }^{15} \mathrm{~N}$ and $\mathrm{PEG}$ at the duodenum over the same period (Smith et al. 1975; Salter \& Smith, 1977b).

Mathematical treatment of data. Inverse quadratic functions (Nelder, 1966) were fitted to the plots of ${ }^{15} \mathrm{~N}$ atoms percent excess in each amino acid against time. The slopes of the curves at zero time were used as estimates of the initial rates of ${ }^{15} \mathrm{~N}$ incorporation.

\section{RESULTS}

The net amounts of bacterial $\mathrm{N}$ synthesized in $24 \mathrm{~h}$, estimated from rumen fluid turnover rates and enrichments of ${ }^{15} \mathrm{~N}$ in bacteria and rumen fluid NAN were $5.6,7.6$ and $6 \cdot 0$ for diets $\mathrm{A}, \mathrm{B}$ and $\mathrm{C}$ respectively. The proportion of ${ }^{15} \mathrm{~N}$ derived from urea recovered in bacteria was found to be 69,54 and $39 \%$, representing $1.6,4.8$ and $6.0 \mathrm{~g} \mathrm{~N}$ for diets $\mathrm{A}, \mathrm{B}$ and $\mathrm{C}$ respectively. Thus it can be calculated that $4 \cdot 0,2 \cdot 8$ and $0.0 \mathrm{~g} \mathrm{~N}$ in rumen bacteria was derived from dietary protein or other $\mathrm{N}$ sources.

The results of amino acid analyses on acid-hydrolysates of whole rumen bacteria prepared from the rumen contents of steers given diets $\mathrm{A}, \mathrm{B}$ or $\mathrm{C}$ are shown in Table 2. The proportion of total bacterial $\mathrm{N}$ that was in the form of amino acid- $\mathrm{N}$ was found to be $82 \mathrm{I}, 814$ and $822 \mathrm{mg} / \mathrm{g}$ bacterial $\mathrm{N}$ respectively for bacteria from steers given diets $\mathrm{A}, \mathrm{B}$ and $\mathrm{C}$ (means for series $I$ and 2). It appeared that the dietary treatment of the donor steers had little influence on the amino acid composition of the bacteria, with the exception that a lower proportion of methionine was found in the rumen bacteria from steers given the high-urea diet $\mathrm{C}$. This was shown for both experimental series. Results were in general compatible with those reported by other workers (Weller, 1957; Hoogenraad \& Hird, 1970; Williams \& Dinusson, 1973), when calculated on a similar basis.

Examples of the changes in concentration and ${ }^{15} \mathrm{~N}$ abundance of ammonia that took place in the rumen after feeding are shown in Fig. I $(a)$ and $(b)$. Concurrent changes in ${ }^{15} \mathrm{~N}$ abundance in bacterial amide- $\mathrm{N}$ and total non-amide-N are also shown in Fig. $\mathrm{I}(c)$ and $(d)$. The ${ }^{15} \mathrm{~N}$ values for rumen ammonia changes were clearest for diet $\mathrm{C}$ as the high content of urea led to considerable and lasting increases in the concentration of ammonia, which could be readily sampled and analysed. For this diet virtually all the soluble ${ }^{15} \mathrm{~N}$ present was in the form of ammonia after $\mathrm{I} h$. Subsequently the ${ }^{15} \mathrm{~N}$ abundance of ammonia- $\mathrm{N}$ decreased steadily during the remainder of the experimental period. There was a rapid initial increase 
Table 2. Amino acid composition (mg amino acid/g total amino acid $+\mathrm{NH}_{3}$ ) of rumen bacteria from steers given diets $A, B$ or $C^{*}$

\begin{tabular}{|c|c|c|c|c|}
\hline Diet $\ldots$ & A & B & $\mathrm{C}$ & $\begin{array}{c}\text { Range of values in } \\
\text { the literature } \dagger\end{array}$ \\
\hline Lysine & $8 I$ & 84 & 84 & $71-82$ \\
\hline Histidine & 17 & 18 & 20 & $17-20$ \\
\hline Arginine & 40 & 47 & 48 & $45-50$ \\
\hline Aspartic acid & 107 & 108 & 108 & $108-120$ \\
\hline Threonine & $5^{8}$ & 51 & 53 & $49-60$ \\
\hline Serine & 46 & 42 & 42 & $34-47$ \\
\hline Glutamic acid & 141 & 139 & 135 & $125^{-1} 37$ \\
\hline Proline & 32 & 29 & 25 & $31-46$ \\
\hline Glycine & 62 & 57 & 53 & $50-6 i$ \\
\hline Alanine & 86 & 87 & 96 & $75-85$ \\
\hline Valine & 59 & 62 & 64 & $60-68$ \\
\hline Methionine & 33 & $3^{8}$ & 17 & $2 \mathrm{I}-34$ \\
\hline Isoleucine & $5 \mathrm{I}$ & 53 & 52 & $58-n 6$ \\
\hline Leucine & 74 & 74 & 75 & $52-84$ \\
\hline Tyrosine & 46 & 46 & 45 & $39-52$ \\
\hline Phenylalanine & 47 & $4^{r}$ & 59 & $49-63$ \\
\hline
\end{tabular}

in the ${ }^{15} \mathrm{~N}$ enrichment of bacterial amide- $\mathrm{N}$ and a slower increase in that of bacterial total non-amide-N. Similar results were obtained for the other diets, but because of the smaller amounts of urea given the average rumen ammonia concentrations were lower and the ${ }^{15} \mathrm{~N}$ enrichments of the ammonia correspondingly higher. Thus the rate of incorporation of ${ }^{15} \mathrm{~N}$ into total bacterial $\mathrm{N}$ was higher for diet $\mathrm{A}$ than diet $\mathrm{C}$. Similarly peak ${ }^{15} \mathrm{~N}$ abundances were higher for diet A than C. Results for diet B were intermediate between those for A and $\mathrm{C}$.

When patterns of ${ }^{15} \mathrm{~N}$ incorporation for individual nitrogenous constituents in the bacteria were examined (examples given in Fig. 2) it was clear that there were differences between them. There was some indication that differences in ${ }^{15} \mathrm{~N}$ abundance between amino acids were greater with diet $A$ than with diet $C$. Initial rates of ${ }^{15} \mathrm{~N}$ incorporation for individual components were calculated from results exemplified by those shown in Fig. 2. It was apparent that both these values and the amounts of ${ }^{15} \mathrm{~N}$ incorporated after a given period of time were different for different nitrogenous components. Absolute values were however influenced by the differing initial ${ }^{15} \mathrm{~N}$ abundance values of the rumen ammonia pools used by the bacteria so that, in order to compare patterns for the different diets it was necessary to consider relative values. Thus initial rates of incorporation of ${ }^{15} \mathrm{~N}$ for individual $\mathrm{N}$ components were expressed for each experiment as a proportion of the mean for that experiment. The values for series 2 experiments, given in the order of decreasing rate for diet $C$ are shown in Fig. 3. Rankings in these terms for series $r$ experiments were generally similar to those for series 2. Amide- $\mathrm{N}$ was always much higher than other $\mathrm{N}$. Glutamic acid, aspartic acid and alanine- $\mathrm{N}$ were usually next highest, whilst proline, galactosamine, phenylalanine, arginine and methionine were generally the lowest. It was clear that certain groups of amino acids incorporated ${ }^{15} \mathrm{~N}$ at a high initial rate irrespective of diet, while others incorporated ${ }^{15} \mathrm{~N}$ more slowly. In the results for series 2 aspartic acid, glycine, tyrosine and glucosamine showed wide differences with diet. The method of calculating initial incorporation rates was very dependent on values at $\mathrm{I} h$ and these variations were most probably due to experimental 

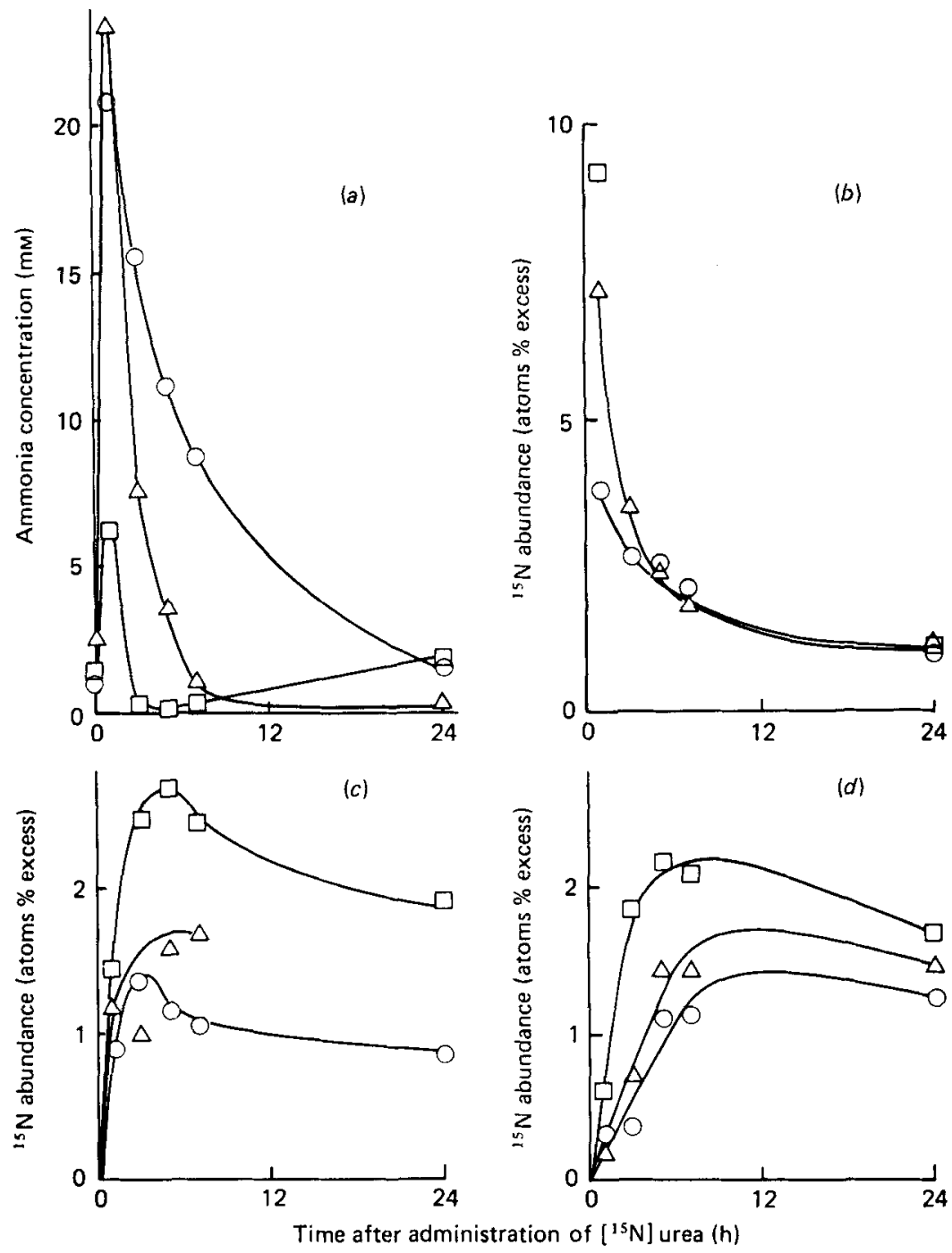

Fig. 1. Variation of (a) concentration (mM) and $(b){ }^{15} \mathrm{~N}$ enrichment (atoms $\%$ excess) of rumen ammonia with time after administration of $\left[{ }^{15} \mathrm{~N}\right] \mathrm{urea}(\mathrm{h})$ and corresponding changes of ${ }^{15} \mathrm{~N}$ enrichment in (c) bacterial amide and $(d)$ total non-amide- $\mathrm{N}$ in series 2 experinents (for details, see $\mathrm{p}$. 198). $\square$, Diet A; $\triangle$, diet B; $O$, diet $C$.

error in I $\mathrm{h}$ values. This appeared to be so for aspartic acid and glucosamine on diet $\mathrm{C}$, for glycine on diet B and for tyrosine on diets B and C. Results for these amino acids are shown separately in Fig. 3. Excluding the most extreme values, results suggest that aspartic acid should be included in the high-rate group, and glycine in the intermediate group. The results for series I experiments confirmed this and showed mean rates of increase for the three diets of 1.65 and 0.83 , for aspartic acid and glycine respectively. The low proportional initial rate of increase of ${ }^{15} \mathrm{~N}$ in arginine with diet $\mathrm{C}$ in series 2 experiments was apparently anomalous, as it did not accord with the high value for ${ }^{15} \mathrm{~N}$ content ultimately reached. Corresponding results for arginine obtained in series I experiments, however, showed higher values with both diets $\mathrm{B}$ and $\mathrm{C}(0.6 \mathrm{r}$ and 0.95 respectively) than with $\operatorname{diet} \mathrm{A}(0.10)$. 


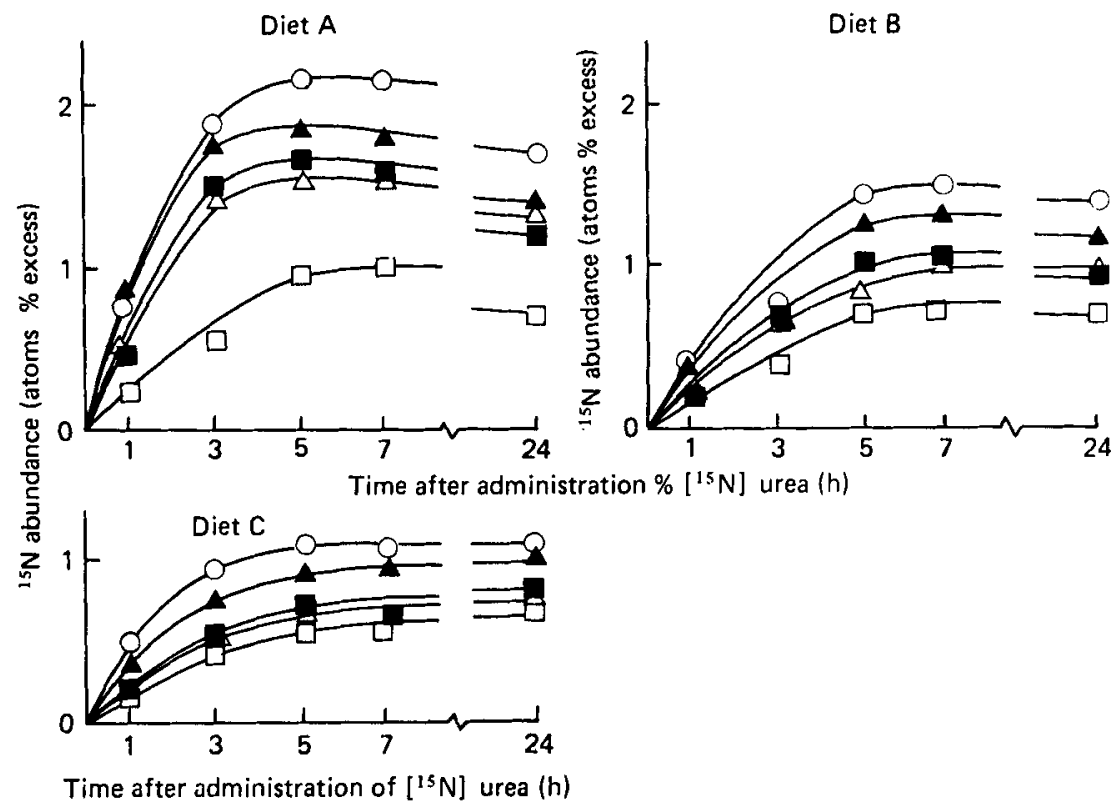

Fig. 2. Variation in ${ }^{15} \mathrm{~N}$ enrichment (atoms \% excess) of bacterial amino acids and total $\mathrm{N}$ with time after administration of $\left[{ }^{15} \mathrm{~N}\right]$ urea $(\mathrm{h}) . \mathrm{O}$, Total bacterial $\mathrm{N} ; \boldsymbol{\Delta}$, glutamic acid; $\boldsymbol{\square}$, threonine; $\triangle$, isoleucine; $\square$, proline; in series 2 experiments (for details, see p. 198).

To compare the effect of the diets on the relative extents of ${ }^{15} \mathrm{~N}$ incorporation into different $\mathrm{N}$ components at different times after the addition of the $\left[{ }^{15} \mathrm{~N}\right]$ urea to the rumen, unbiased by differences in the initial isotopic abundances in rumen $\mathrm{NH}_{3}$, results were expressed in terms of the relative ${ }^{15} \mathrm{~N}$ abundance, where:

$$
\text { 1elative }{ }^{15} \mathrm{~N} \text { abundance }=\frac{{ }^{15} \mathrm{~N} \text { atoms } \% \text { excess in } \mathrm{N} \text { component }}{{ }^{15} \mathrm{~N} \text { atoms } \% \text { excess in total bacterial } \mathrm{N}} .
$$

Typical results for changes in relative ${ }^{15} \mathrm{~N}$ abundance for amino acids and amide- $\mathrm{N}$ with the three diets are shown for series 2 experiments in Fig. 4. Results for series I experiments were similar.

The same general trends in relative ${ }^{15} \mathrm{~N}$ abundance of the $\mathrm{N}$ components with time after addition of $\left[{ }^{15} \mathrm{~N}\right]$ urea were observed with all three diets. Thus the relative ${ }^{15} \mathrm{~N}$ abundance of amide- $\mathrm{N}$ rapidly reached a high maximum value (between $\mathrm{o}$ and $\mathrm{I} \mathrm{h}$ ) and thereafter decreased, whilst that of other amino acid $\mathrm{N}$ increased more slowly to reach an approximately constant value ('plateau') between 3 and $7 \mathrm{~h}$ after giving the $\left[{ }^{15} \mathrm{~N}\right]$ urea. Although the pattern of change in relative ${ }^{15} \mathrm{~N}$ abundance of amide- $\mathrm{N}$ and amino acid- $\mathrm{N}$ with time after addition of $\left[{ }^{15} \mathrm{~N}\right]$ urea was similar with all three diets, the actual values for individual amino acids differed markedly between diets.

The influence of diet on the incorporation of ${ }^{15} \mathrm{~N}$ may be demonstrated by comparing 'plateau' values (i.e. the means of the 3,5 and $7 \mathrm{~h}$ values) of the relative ${ }^{15} \mathrm{~N}$ abundance of different amino acids. These are shown in Fig. 5 for both series 1 and 2 experiments. For the majority of amino acids showing high and intermediate labelling no consistent differences or trends in relative ${ }^{15} \mathrm{~N}$ abundance as the proportion of protein to urea in the diets decreased were observed. However, for histidine, proline and arginine, which were poorly labelled with diet $\mathrm{A}$, the plateau value was consistently higher when the steers were given diet $\mathrm{C}$ (urea as the only $\mathrm{N}$ source) whilst with diet $\mathrm{B}$ results were generally between the other two 


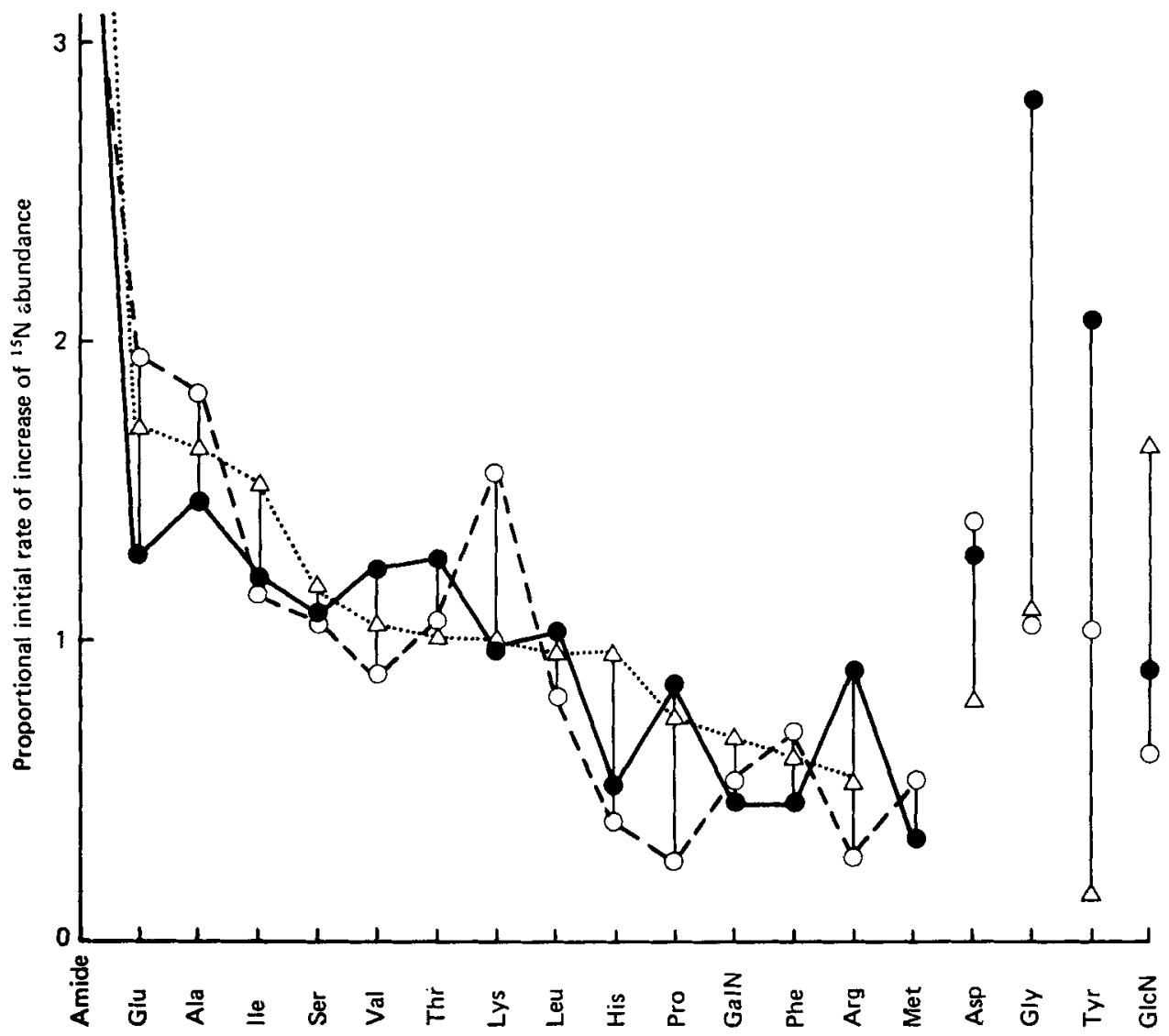

Fig. 3. Initial rates of increase of ${ }^{15} \mathrm{~N}$ (atoms \% excess/h) in $\mathrm{N}$ compounds of bacteria from steers given three different diets, expressed as a proportion of the mean rate for each diet. The values for amide ${ }^{25} \mathrm{~N}$ were $3.7,9.2$ and 10.4 for diets $\mathrm{A}, \mathrm{B}$ and $\mathrm{C}$, respectively. $\mathrm{O}=\mathrm{O}$, Diet $\mathrm{A}$; diet $B ; \triangle \cdots \Delta$, diet $\mathbf{C}$. For details of diets, see Table $\mathbf{I}$.

diets. There was also an indication of a similar trend to higher labelling with diet $\mathrm{C}$ for diaminopimelic acid (DAPA), but measurements were made only for the second series of experiments. For methionine it appeared that the trend was in the reverse direction while the other poorly labelled amino acids, phenylalanine and tyrosine, showed no consistent change in relative ${ }^{15} \mathrm{~N}$ abundance with change of diet.

\section{DISCUSSION}

Since, as expected, $\left[{ }^{15} \mathrm{~N}\right]$ urea was rapidly hydrolysed to ammonia in the rumen, the first experimental sample, taken I $h$ after dosing, showed the highest ${ }^{15} \mathrm{~N}$ abundance in ammonia. The steady decrease in this value subsequently was due to the net effect of a variety of factors, including entry of ${ }^{15} \mathrm{~N}$ into bacteria, outflow of digesta from the reticulorumen to the lower alimentary tract, absorption of ammonia across the rumen wall and the dilution of the remaining ammonia with that derived directly or catabolically from endogenous secretions, microbial turnover or dietary intake (particularly DCGM from diets A and B).

The rapid increase in bacterial amide- ${ }^{15} \mathrm{~N}$ enrichment to a maximum at approximately $4-5 \mathrm{~h}$ and the slower increase in bacterial non-amide- ${ }^{15} \mathrm{~N}$ to a maximum approximately $4 \mathrm{~h}$ later (Figs. I and 3) presumably represented first mainly accretion and then use of $\mathrm{N}$ for 


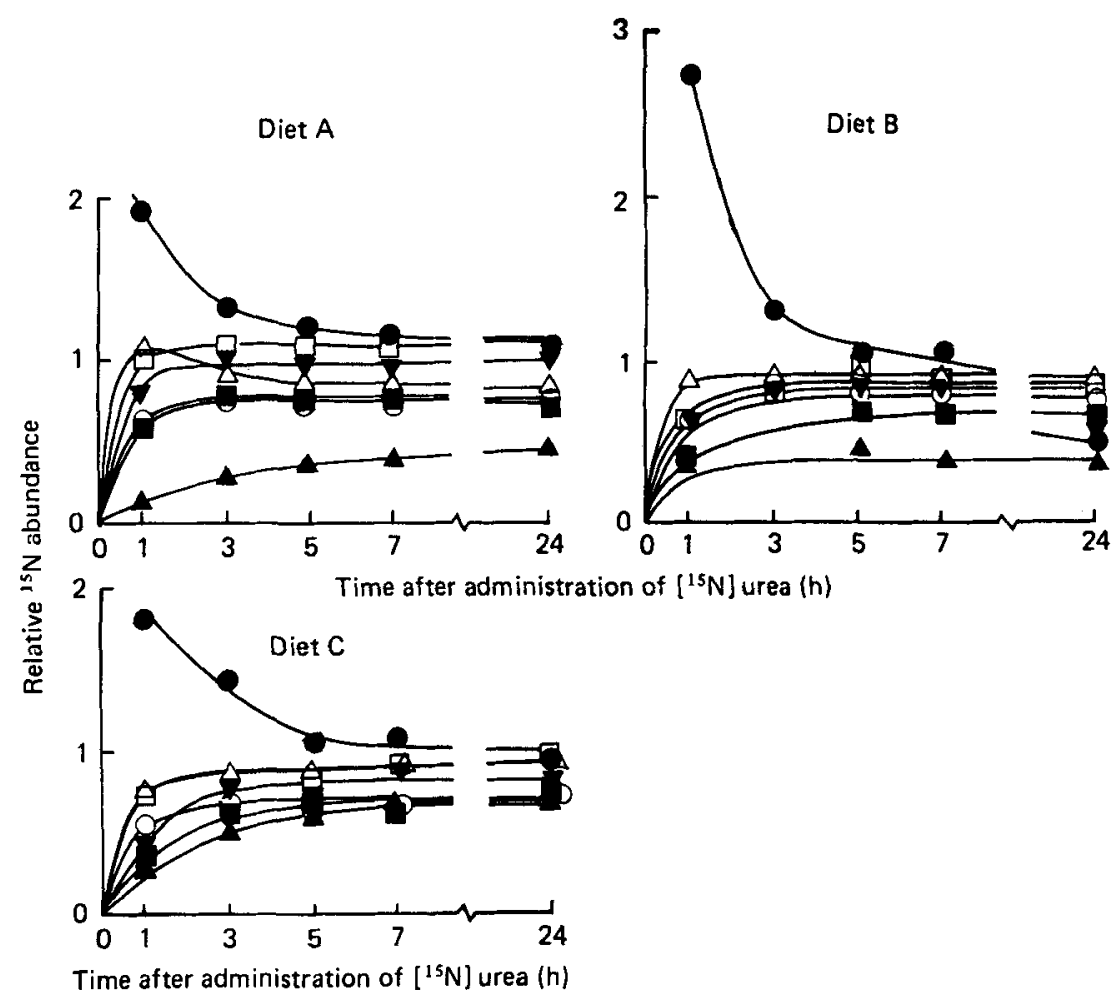

Fig. 4. Variation in relative ${ }^{15} \mathrm{~N}$ abundance of rumen bacterial amino acids with time after administration of [ $\left.{ }^{15} \mathrm{~N}\right]$ urea $(h)$ to the rumen of a steer given diets $\mathrm{A}, \mathrm{B}$ or $\mathrm{C}$ in series 2 experiments (for details see Table I). $\bigcirc$, Amide; $\triangle$, glutamic acid; $\square$, aspartic acid; $\nabla$, lysine; $\bigcirc$, isoleucine; $\boldsymbol{\square}$, threonine; $\boldsymbol{\Delta}$, arginine. For definition of relative ${ }^{15} \mathrm{~N}$ abundance, see p. 203.

amino acid synthesis by the bacteria, either from an appropriate $\mathrm{C}$ skeleton or from more primitive units. The incorporation of ${ }^{15} \mathrm{~N}$ does not necessarily imply de novo synthesis of amino acids since it may also occur via transamination reactions. The observed differences between amino acids in initial rates of ${ }^{15} \mathrm{~N}$ incorporation (Figs. 2 and 3 ) indicated, however, considerable variation between the contributions of this synthesis to the different amino acids used by the bacteria for growth. Differences tended to be greatest when the diet containing the most protein was given but this effect was not clear cut. For all diets it was apparent that of all the amino acids, glutamic acid and alanine, together, in most experiments, with aspartic acid, became most rapidly labelled. These substances presumably acted as initial recipients of amino groups for subsequent transfer to other amino acids: the results support a scheme in which $\mathrm{NH}_{3} \rightarrow$ amide $\rightarrow$ glutamate $\rightarrow$ aspartic acid and alanine $\rightarrow$ other amino acids. The enzymes for all these processes have recently been identified and studied by Erfle et al. (1977). It was found that enzymes of $\mathrm{NH}_{4}{ }^{+}$assimilation as well as amino acid biosynthesis and utilization by rumen micro-organisms in vitro in continuous culture could be regulated by the concentration of $\mathrm{NH}_{4}{ }^{+}$. Extracts of the mixed rumen bacteria contained glutamate synthase (EC 2.6.1.53) activity as well as glutamine and asparagine synthetases (EC 6.3.1.2 and EC 6.3.1.I respectively), which together could provide an efficient means of glutamate synthesis at low rumen ammonia concentrations. Unlike asparagine synthetase, both glutamate synthase and glutamine synthetase decreased in activity at higher $\mathrm{NH}_{4}{ }^{+}$concentrations, whilst the formation of alanine presumably from glutamate by alanine aminotransferase (EC 2.6.1.2) increased rapidly at high ammonia 

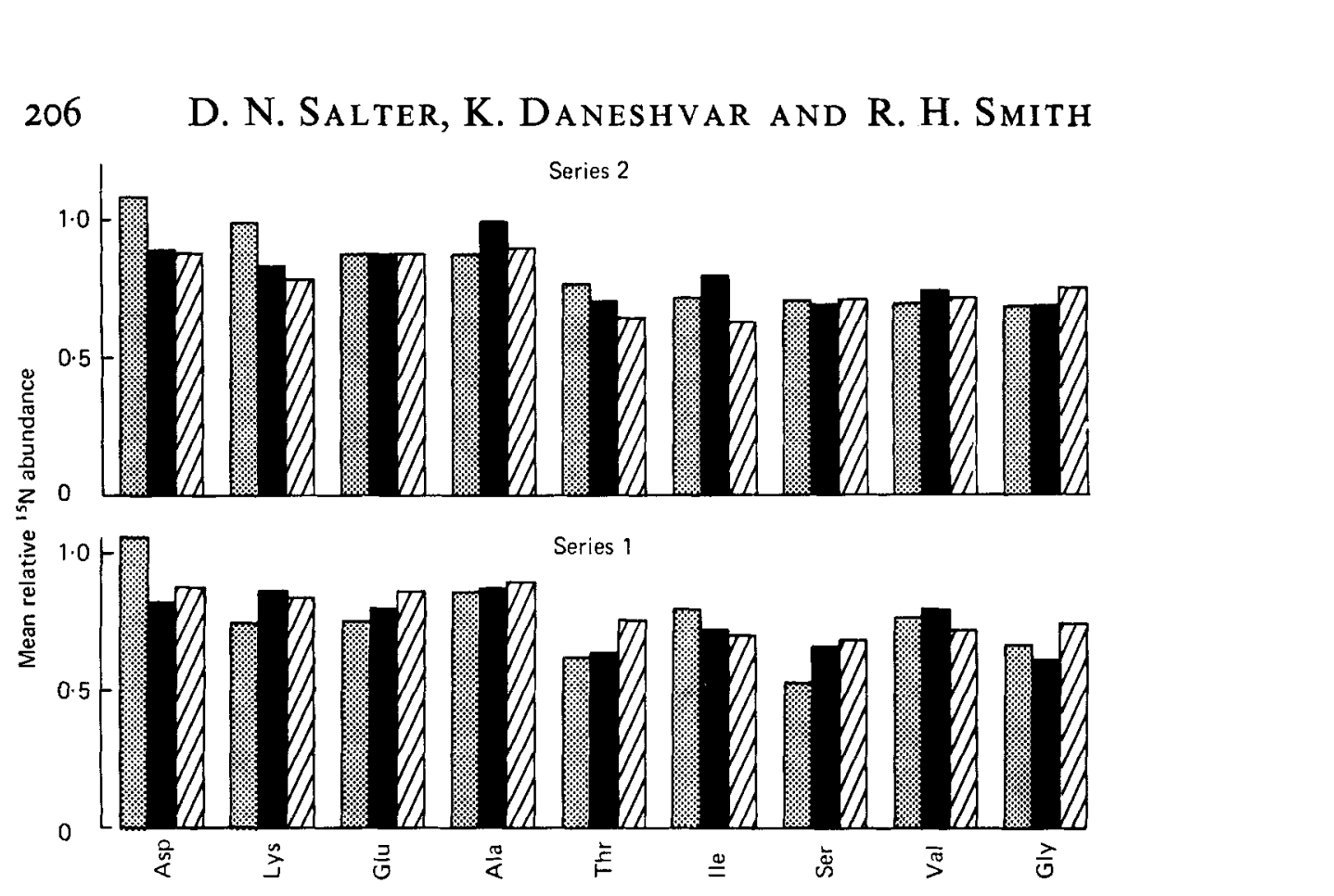

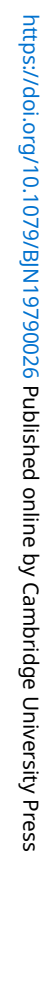

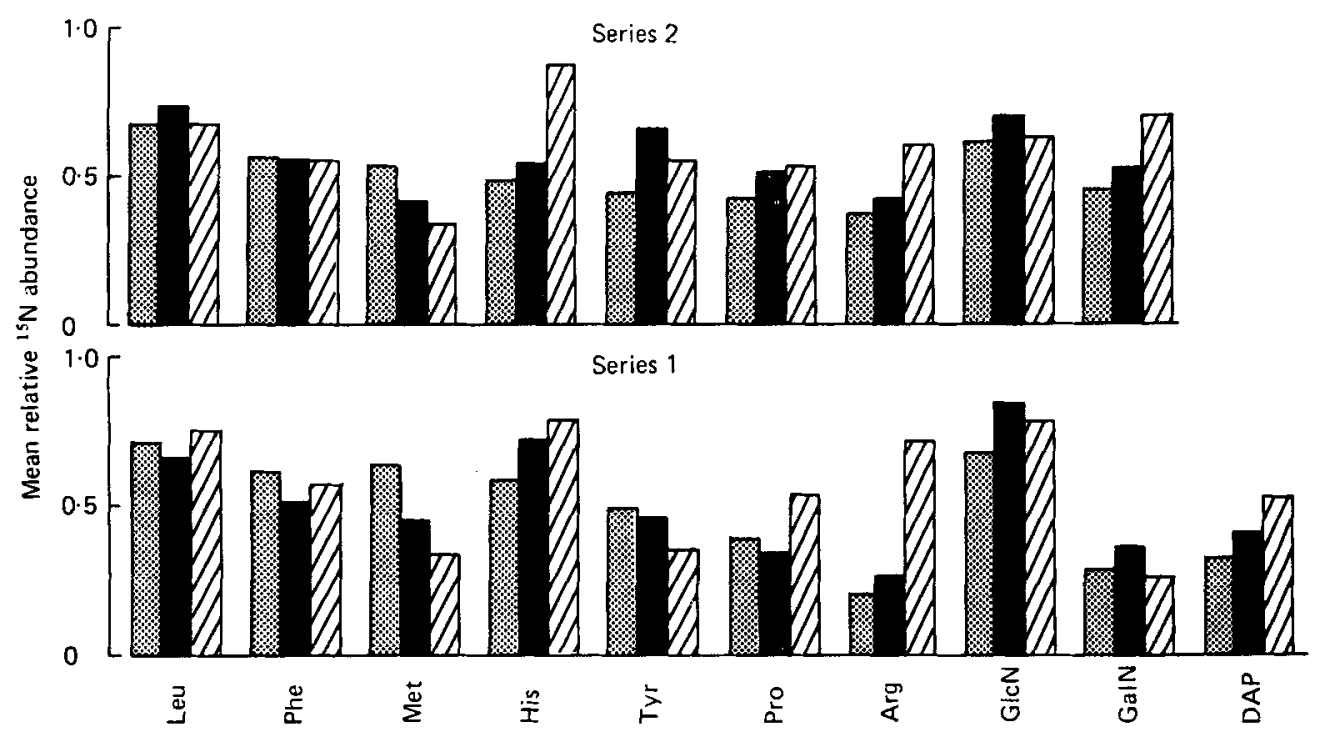

Fig. 5. Influence of diet on the mean value of relative ${ }^{15} \mathrm{~N}$ abundance in different $\mathrm{N}$ compounds of rumen bacteria for samples taken at 3,5 and $7 \mathrm{~h}$ after giving $\left[{ }^{15} \mathrm{~N}\right]$ urea. Results for series $\mathrm{I}$ and 2 experiments (for details, see p. 198 ). 囷, Diet A; $\mathbf{m}$, diet $\mathrm{B} ; \mathbb{Z}$, diet C. For definition of relative ${ }^{15} \mathrm{~N}$ abundance, see text. DAPA, diaminopimelic acid. 
concentrations. The fixation of ammonia by glutamate dehydrogenase (EC I.4.I.2 and I.4. I.4) was also demonstrated and appeared to be unaffected by variation in ammonia concentration. The pathways for the production of the $\mathrm{C}$ skeletons for the synthesis of many amino acids have also been elucidated (Kristensen, 1974; Sauer et al. 1975).

Comparisons of changes in relative ${ }^{15} \mathrm{~N}$ abundance values for individual components in the bacteria and the 'plateau' values achieved (Fig. 4) also indicated that there were differences in relative amounts of the different amino acids which were, on the one hand, synthesized and therefore labelled with ${ }^{15} \mathrm{~N}$ or, on the other, incorporated directly from peptides or amino acids derived from unlabelled protein. In steers given the essentially protein-free diet $\mathrm{C}$ the only preformed unlabelled amino acids available would be from turnover of existing bacterial cells. This might be expected to narrow the range of ${ }^{15} \mathrm{~N}$ abundances observed and this was indeed found to be the situation.

From the mean 'plateau' values for relative ${ }^{15} \mathrm{~N}$ abundance (Fig. 5) a clearer comparison of the extent to which different amino acids were derived from protein when this was included in the diet (diets A and B) was apparent. Generally the amino acids labelled to the smallest extent and therefore presumably derived to the greatest extent from preformed units were also those found to be synthesized most slowly (Fig. 3); the most clear examples were proline and arginine, although DAPA, galactosamine, phenylalanine, tyrosine, histidine and methionine also tended to be labelled to a smaller extent than average. It is of interest that when Shimbayashi et al. (1975) incubated $\left[{ }^{15} \mathrm{~N}\right]$ urea with rumen contents in vitro and measured the incorporation of ${ }^{15} \mathrm{~N}$ into a fraction that sedimented on centrifuging, they found relatively high enrichments in glycine, alanine, glutamic acid and aspartic acid and very low enrichments in methionine and cystine. They also observed low enrichments in histidine, arginine and phenylalanine. Although the precise constitution of the fraction that they examined was not clear, these results lend support to the present findings.

DAPA needs to be considered in a different way from the other amino acids as it is deposited primarily in the bacterial cell walls; its low labelling may represent a slower turnover of cell wall material compared to that of protein within the bacterial cell. The hexosamines also need separate consideration. Assuming that relative proportions of DAPA and these compounds in the bacteria did not change greatly during an experimental period and that none of the compounds were incorporated in a preformed state, the evidence implies that galactosamine and DAPA were turned over at approximately the same rate but that glucosamine was turned over more rapidly.

There are several possible reasons for differences in labelling of amino acids incorporated mainly into bacterial protein. Amino acids liberated from dietary or other protein by proteolysis are also degraded in the rumen and amounts available for incorporation into growing bacteria will depend upon the net effect of these processes. Some amino acids appear to be more resistant than others when added to rumen contents in vitro (Scheifinger et al. 1975; Skoch et al. 1975) but, in vivo, free amino acids are generally found in rumen fluid in very low concentrations (Wright \& Hungate, 1967) and the in vitro differences probably bear little relation to what happens to amino acids released by proteolysis in vivo. Certainly arginine, for example, appears to be exceptionally rapidly degraded in vitro (Lewis \& Emery, I 962) although it also appeared to be extensively incorporated into growing bacteria (Fig. 5). It seems most likely that different amounts of ${ }^{15} \mathrm{~N}$ labelling are determined primarily by the availability of different pathways within the bacteria. It is possible that a bacterial population would make use of some preformed amino acids if these were available from dietary protein but might suffer no serious disadvantage if this source were removed so that the amino acids had to be synthesized. Such an explanation is compatible with the findings observed for arginine and histidine which became relatively more highly labelled with ${ }^{15} \mathrm{~N}$ when a nearly protein-free diet was given, whilst there was some indication of a similar 
response for proline. On the other hand if a synthetic pathway for a particular amino acid were limited and could not increase, even if preformed units were not supplied, then bacterial growth might be limited by the supply of that amino acid. It appears that phenylalanine and its derivative, tyrosine, may be in this category as their low extent of ${ }^{15} \mathrm{~N}$ labelling did not change appreciably on a protein-free diet.

The importance of preformed methionine in the nutrition of mixed rumen bacteria has been a subject of some controversy. Some pure strains of rumen bacteria have a requirement for methionine or other sulphur-containing amino acids (Pittman \& Bryant, 1964) but with considerable turnover of bacteria in the rumen (Nolan \& Leng, 1972; Smith \& Smith, 1977 ) it is possible that such needs may be met from species capable of synthesizing these compounds. The results of Nader \& Walker (1970) supported this view and indicated that inappreciable amounts of methionine were directly incorporated into mixed rumen bacteria. Other workers, however, have shown that such incorporation can be considerable (Gawthorne \& Nader, 1976; McMeniman et al. 1976). It is likely that different populations may behave differently but under our conditions for steers given the protein-containing diets preformed methionine, when available, appeared to be used to a greater extent than most other amino acids for bacterial protein synthesis. More important, the same was true even when protein was omitted from the diet, indicating that methionine synthesis could not increase to compensate for a decreased supply of preformed material. It is of interest that the methionine content of the bacteria appeared to be depressed when the protein-free diet $\mathrm{C}$ was given. This result seems unlikely and further work will be necessary to check the effect of non-protein urea-containing diets on the methionine content of rumen bacteria. The further decrease in relative ${ }^{15} \mathrm{~N}$ abundance of methionine with diet $\mathrm{C}$ might be indicative of a lack of precursor for transamination in the absence of supplementary protein.

Other factors which have been proposed as possibly limiting bacterial growth in the rumen are the branched-chain amino acids leucine, isoleucine and valine as it has been shown that certain strains of rumen bacteria require these compounds or the corresponding C skeletons (Bryant, 1973). There was, however, no evidence from the present work that these amino acids were incorporated directly into bacterial protein to a greater extent than other amino acids; presumably the required $C$ skeletons were available in adequate amounts.

It has become increasingly apparent in recent years (Nolan et al. 1976) that mixed rumen bacterial populations generally make use of considerable amounts of preformed amino acids as nitrogenous nutrients. It is plausible to suppose that if the supply of such amino acids is limited by giving a diet high in non-protein- $\mathrm{N}$ and low in protein then the efficiency of bacterial growth may be depressed. Except for the results of Maeng \& Baldwin (1976), however, there is little evidence to support this view unequivocally. The present results indicate the possibility that methionine and phenylalanine may be involved in such a limitation. The evidence is stronger for the first but an unequivocal demonstration of a response in synthetic efficiency by a mixed bacterial population to supplements of these compounds is needed.

The authors are grateful to Dr H. L. Buttle and Mr S. C. Watson for carrying out the surgical operations, to Miss C. L. Phillips for the care of the steers, to Miss P. E. Lewis and Mrs A. Hudson for skilled technical assistance, and to Mr S. Morant for the calculation of initial rates of ${ }^{15} \mathrm{~N}$ incorporation.

\section{REFERENCES}

Bryant, M. P. (1973). Fedn Proc. Fedn Am. Socs e.xp. Biol. 32, i809.

Conway, E. J. ( I957). Microdiffusion Analysis and Volumetric Error, p. 98 . London: Crosby \& Lockwood.

Daneshvar, K. (1976). Studies with ${ }^{15} \mathrm{~N}$ of the incorporation in the rumen of non-protein nitrogen into microbial protein and nucleic acids. PhD Thesis, University of Reading. 
Daneshvar, K., Salter, D. N. \& Smith, R. H. (1976). Proc. Nutr. Soc. 35, 52A.

Erfle, J. D., Sauer, F. D. \& Mahadevan, S. (1977). J. Dairy Sci. 60, ro64.

Gawthorne, J. M. \& Nader, C. J. (1976). Br.J. Nutr. 35, II.

Hoogenraad, N. J. \& Hird, F. J. R. (1970), Br. J. Nutr. 24, I 19.

Hume, I. D. (1970). Aust. J. agric. Res. 21, 305.

Kristensen, S. (1974). Br. J. Nutr. 31, 357.

Lewis, T. R. \& Emery, R. S. (1962). J. Dairy Sci. 45, 765.

Lloyd-Jones, C. P., Adam, J. \& Salter, D. N. (1975). Analyst, Lond. 100, 891.

McMeniman, N. P., Ben-Ghedalia, D. \& Elliott, R. (1976). Br. J. Nutr. 36, 571.

Maeng, W. J. \& Baldwin, R. L. (1976). J. Dairv Sci. 59, 648.

Nader. C. J. \& Walker, D. J. (1970). Appl. Microbiol. 20, 677.

Nelder, J. A. (1966). Biometrics 22, 128.

Nolan, J. V. \& Leng, R. A. (1972). Br. J. Nutr. 27, 177.

Nolan, J. V., Norton, B. W. \& Leng, R. A. (1976). Br. J. Nutr. 35, 127.

Pittman, K. A. \& Bryant, M. A. (1964). J. Bact. 88, 40I.

Roy, J. H., Balch, C. C.., Miller, E. L., Ørskov, E. R. \& Smith, R. H. (I977). Publs Eur. Ass. Anim. Prod. 22, 126.

Salter, D. N., Daneshvar, K. \& Smith, R. H. (1976). Proc. 1oth Int. Cong Biochem., Hamburg, p. 671.

Salter, D. N. \& Smith, R. H. (1977a). Br. J. Nutr. 38, 207.

Salter, D. N. \& Smith, R. H. (1977 b). Proc. Nutr. Soc. 36, 54A.

Sauer, F. D., Erfle, J. D. \& Mahadevan, S. (1975). Biochem. J. r50, 357.

Scheifinger, C., Russell, N. \& Chalupa, W. (1975). Fedn Proc. Fedn Am. Socs exp. Biol. 34, 902.

Shimbayashi, K., Obara, Y. \& Yonemura, T. (i975). Jap. J. Zootech. Sci. 46, 243.

Skoch, S. A., Schelling, G. T., Tucker, R. E. \& Mitchell, G. E. (1975). J. Anim. Sci. 40, 197.

Smith, R. C. \& Smith, R H. (1977). Br. J. Nutr. 37, 389.

Smith, R. H. (1976). In Digestion and Metabolism in the Ruminant, p. 399 [I. W. McDonald and A. C. I. Warner, editors] Armidale: University of New England.

Smith, R. H., Salter, D. N., Sutton, J. D. \& McAllan, A. B. (1975). In Tracer Studies on Non-protein Nitrogen for Ruminants. II. (Proc. Research Coordination Meeting, Vienna, 1974) I.A.E.A., Vienna.

Weller, R. A. (1957). Aust. J. biol. Sci. 10, 384.

Williams, P. P. \& Dinusson, W. E. (1973). J. Anim. Sci. 36, 15 I.

Wright, D. E. \& Hungate, R. E. (1967). Appl. Microbiol. 15, I48. 